\begin{abstract}
Iranica
Abstracta Iranica Revue bibliographique pour le domaine irano-aryen

Volume 32-33 | 2013

Comptes rendus des publications de 2009-2010
\end{abstract}

\title{
Sebastian P. Brock. A Brief Outline of Syriac Literature
}

\section{Florence Jullien}

\section{(2) OpenEdition \\ 12 Journals}

\section{Édition électronique}

URL : http://journals.openedition.org/abstractairanica/40822

DOI : 10.4000/abstractairanica.40822

ISSN : 1961-960X

Éditeur :

CNRS (UMR 7528 Mondes iraniens et indiens), Éditions de l'IFRI

\section{Édition imprimée}

Date de publication : 1 décembre 2013

ISSN : 0240-8910

\section{Référence électronique}

Florence Jullien, « Sebastian P. Brock. A Brief Outline of Syriac Literature », Abstracta Iranica [En ligne], Volume 32-33 | 2013, document 319, mis en ligne le 01 juillet 2016, consulté le 26 septembre 2020. URL : http://journals.openedition.org/abstractairanica/40822 ; DOI : https://doi.org/10.4000/ abstractairanica. 40822

Ce document a été généré automatiquement le 26 septembre 2020.

Tous droits réservés 


\title{
Sebastian P. Brock. A Brief Outline of Syriac Literature
}

\author{
Florence Jullien
}

\section{RÉFÉRENCE}

Sebastian P. Brock. A Brief Outline of Syriac Literature. Kottayam, 2009, $2^{\mathrm{e}}$ éd, 290 p.

(Moran Etho 9).

L'A. offre dans ce volume un panorama utile sur l'histoire de la production littéraire en langue syriaque du II ${ }^{e}$ s. à nos jours - l'âge d'or restant les IV eVII $^{e}$ siècles. Six chapitres couvrent l'espace-temps, avec une présentation des principaux auteurs et écrits, regroupés selon des thématiques telles que la liturgie, la littérature monastique, les chroniques, l'exégèse ou la littérature profane, la Bible... Une petite chrestomathie pour chaque période considérée suit une bibliographie sélective.

\section{AUTEURS}

\section{FLORENCE JULLIEN}

EPHE, Paris 